(c) American Dairy Science Association, 2005.

\title{
Development of an Adult-Like Cell-Mediated Immune Response in Calves After Early Vaccination with Mycobacterium bovis bacillus Calmette-Guérin*
}

\author{
B. J. Nonnecke, ${ }^{1}$ W. R. Waters, ${ }^{2}$ M. R. Foote ${ }^{3}$ M. V. Palmer, ${ }^{2}$ B. L. Miller, ${ }^{4}$ \\ T. E. Johnson, ${ }^{4}$ H. B. Perry, ${ }^{4}$ and M. A. Fowler ${ }^{5}$ \\ ${ }^{1}$ Periparturient Diseases of Cattle Research Unit, and \\ ${ }^{2}$ Bacterial Diseases of Livestock Research Unit, National Animal Disease Center, \\ USDA Agricultural Research Service, Ames, IA 50010 \\ ${ }^{3}$ Department of Animal Science, lowa State University, Ames 50011 \\ ${ }^{4}$ Land O'Lakes, Inc., Research Farm, Box 65, Webster City, IA 50595 \\ 5Land O'Lakes, Inc., PO Box 64404, St Paul, MN 55164
}

\begin{abstract}
Effects of neonatal vaccination on antigen-specific cellular and humoral immune responses of dairy calves have not been well described. The purpose of this study was to characterize the ontogeny of the adaptive immune response in calves sensitized to the attenuated strain of Mycobacterium bovis, bacillus Calmette-Guérin. Holstein bull calves were nonvaccinated $(\mathrm{n}=6$, vaccination controls) or vaccinated subcutaneously ( $\mathrm{n}=$ 6) with bacillus Calmette-Guérin at 1 and 7 wk of age. Composition and functional capacities of blood mononuclear cell populations from calves were evaluated at 1 (prevaccination), 3, 6, 7, 8, 9, and $12 \mathrm{wk}$ of age. Young adults (nulliparous heifers, $\mathrm{n}=4$ ) vaccinated in an identical manner were sampled concurrently to evaluate effects of animal maturity on the development of the adaptive immune response. Responses of nonvaccinated calves to recall antigen (Mycobacterium bovis purified protein derivative) ex vivo and in vivo (i.e., cutaneous delayed-type hypersensitivity) were minimal or nonexistent. Responses of cells from vaccinated calves and young adults to recall antigen, however, were evident as early as wk 2 after primary vaccination. Antigen-induced $\mathrm{T}$ cell subset proliferation, and secretion of interferon- $\gamma$, nitric oxide, and tumor necrosis factor$\alpha$ by cells from vaccinated calves were comparable to or greater than responses of vaccinated adults during the 11-wk study. Eleven weeks after primary vaccination, cutaneous responses of vaccinated calves and
\end{abstract}

Received July 9, 2004.

Accepted September 21, 2004.

Corresponding author: B. J. Nonnecke; e-mail: bnonneck@nadc. ars.usda.gov.

*Names are necessary to report factually on available data; however, the USDA neither guarantees nor warrants the standard of the product, and use of the name by the USDA implies no approval of the product to the exclusion of others that may also be suitable. young adults to intradermal administration of antigen were pronounced and comparable, demonstrating the capacity of the bovine neonate to develop a vigorous cellmediated immune response in vivo. Antibody responses (i.e., antibody concentrations in sera and in supernatants from antigen-stimulated cultures of blood mononuclear cells) of vaccinated calves, in contrast, were markedly lower than parallel responses of vaccinated adults. In conclusion, these results suggest that the bovine neonate can mount a vigorous, adult-like cellmediated immune response when vaccinated at an early age.

(Key words: neonatal vaccination, adaptive immunity, Mycobacterium bovis BCG, calf)

Abbreviation key: BCG = bacillus Calmette-Guérin, FBS = fetal bovine serum, PBMC = peripheral blood mononuclear cells, PBST = PBS with Tween 80, PBST$\mathbf{g}=$ PBST with gelatin, $\mathbf{P P D}=$ purified protein derivative, PPDa $=$ Mycobacterium avium-derived PPD, $\mathbf{P P D b}=$ Mycobacterium bovis-derived PPD, PWM = pokeweed mitogen, $\mathbf{T h} \mathbf{1}=\mathrm{T}_{\text {helper }}$ 1-type response, $\mathbf{T h} \mathbf{2}=$ $\mathrm{T}_{\text {helper }} 2$-type response, TNF: tumor necrosis factor, WCS-PK = proteinase K-digested whole cell sonicate of Mycobacterium bovis BCG.

\section{INTRODUCTION}

Effects of early vaccination on the adaptive immune response of the neonatal calf have not been well described. Protection afforded by early vaccination is critical given the diversity and number of potential pathogens in the calf's environment. The immune system of the neonate, however, is considered developmentally immature and incapable of mounting adult-like responses to antigenic stimulation (Adkins, 2000; Morein et al., 2002). Developmental immaturity of the calf's immune system may compromise the efficacy of vacci- 
nation protocols and exacerbate the calf's susceptibility to infectious disease.

The neonatal immune system is characterized by a T-cell population with a high proportion of naïve $\mathrm{T}$ cells that can suppress Ig production (Clement et al., 1990). Neonates also have higher proportions of antigen-presenting cells with defective costimulatory activity (Ridge et al., 1996) and a decreased capacity to produce cytokines, particularly those associated with $\mathrm{T}_{\text {helper }} 1$ (Th1) responses (Adkins, 2000; Siegrist, 2000). The Th1-biased response is necessary for protection against viruses and intracellular bacteria, and is characterized by the predominant production of IFN- $\gamma$. In infant mice, exposure to antigen leads to a $\mathrm{T}_{\text {helper }} 2$ (Th2)-biased response characterized by IL- 4 secretion and antibody responses predominated by the Ig isotype, $\operatorname{IgG}_{1}$. The ruminant animal (calf) is unique in that it is agammaglobulinemic when born and relies on ingestion of colostrum for acquisition of maternal immunoglobulin (passive immunity) and viable leukocytes (adoptive immunity) to afford protection against infection. Although maternally derived immune factors provide early protection, they may interfere with postnatal activation of the calf's own immune system and its capacity to mount a protective response to vaccination or infection. In humans, inhibition of the infant's responses to vaccination by maternal antibody is B-cell specific, depends on antibody titer and dose of vaccine antigen, and does not appear to influence responses of T cells (Siegrist, 2003).

Experiments demonstrating cell-mediated immunity frequently use animals immunized with Mycobacterium bovis. When challenged with mycobacterial antigens, a protective Th1 response is triggered in sensitized individuals. Infusion of tuberculin into the mammary glands of cows sensitized to mycobacteria results in antigen-specific mammary and peripheral responses characteristic of a cell-mediated immune response (Nickerson and Nonnecke, 1986; Nonnecke et al., 1986). Results from a recent study (Hope et al., 2002) indicate that in the neonate, $\mathrm{CD}^{+} / \mathrm{CD}^{+}$natural killer cells produce IFN- $\gamma$ in response to dendritic cells infected with attenuated $M$. bovis strain, bacillus Calmette-Guérin (BCG). Human newborns immunized with BCG develop Th1 responses of similar magnitude to those produced by adults (Marchant et al., 1999; Vekemans et al., 2001; Ota et al., 2002). These observations suggest that a BCG sensitization/purified protein derivative (PPD) challenge model might provide new information regarding the ontogeny of the adaptive arm of the immune system of the neonatal calf.

Objectives of this study were to characterize and compare adaptive (antigen-specific) immune responses of young and adult dairy cattle using a BCG sensitization and PPD challenge model. Of particular interest was the comparison of the magnitude and make-up of cellular and humoral responses of calves and young adults during the 11-wk period after primary vaccination with BCG.

\section{MATERIALS AND METHODS}

\section{Animals and Treatments}

Twelve age-matched male Holstein calves housed at the Land O'Lakes Research Farm, Webster City, IA, and 4 young adults (nulliparous heifers) housed at the National Animal Disease Center, U. S. Department of Agriculture, Agriculture Research Service, Ames, IA, were used. Calves were chosen for inclusion in the study if their serum gamma globulin concentrations were indicative of successful passive immunity. At the initiation of the study, calves were approximately $7 \mathrm{~d}$ of age (range: 3 to $10 \mathrm{~d}$ of age). Animal-related procedures were implemented following institutional guidelines for animal care. From 1 to 7 wk of age, calves were housed on elevated stalls in an indoor, ventilated environment. During this period they were fed milk replacer $(0.57$ $\mathrm{kg} / \mathrm{d}$, comprising $22 \% \mathrm{CP}$ and $20 \%$ fat; Land O'Lakes, Inc.) and calf starter (ad libitum, 18\% texturized CP; Land O'Lakes, Inc.) with lasalocid acid. Calves were weaned at $7 \mathrm{wk}$ of age. During the postweaning phase of the study (7 to 12 wk of age), calves were housed outdoors in free-stalls bedded in straw and were fed a diet of $18 \%$ texturized crude protein $(2.7 \mathrm{~kg} / \mathrm{d})$ with lasalocid $(0.46 \mathrm{~g} / 10 \mathrm{~kg}$ of $\mathrm{CP})$. Hay was provided ad libitum.

Before vaccination, young adults were tested and confirmed negative for $M$. bovis and Mycobacterium avium exposure using a commercially available assay (Bovigam, CSL Ltd., Parkville, Victoria, Australia) to evaluate the responsiveness of blood lymphocytes to mycobacterial antigens. Adults were housed outdoors, received water ad libitum and a balanced ration consisting of pelletized alfalfa and grain.

\section{Preparation and Administration of BCG Vaccine}

The BCG (Pasteur strain) was grown in Middlebrook's $7 \mathrm{H} 9$ media supplemented with $10 \%$ oleic acid-albumin-dextrose complex (Difco, Detroit, MI) plus 0.05\% Tween 80 (Sigma Chemical Co., St. Louis, MO) as described for virulent $M$. bovis (Bolin et al., 1997). Briefly, mid log-phase growth bacilli were pelleted by centrifugation at $750 \times \mathrm{g}$, washed twice with PBS $(0.01$ $M, \mathrm{pH} 7.2$ ), and diluted to the appropriate cell density in $2 \mathrm{~mL}$ of PBS. Bacilli were enumerated by serial dilution plate counting on Middlebrook's 7H11 selective media (Becton Dickinson, Cockeysville, MD). 
Table 1. Primary and secondary antibodies used in the phenotypic analysis of blood mononuclear cell populations from neonatal calves and nulliparous heifers.

\begin{tabular}{|c|c|c|c|c|}
\hline $\begin{array}{l}\text { Primary antibody } \\
\text { specificity }\end{array}$ & Clone $^{1}$ & Isotype & $\begin{array}{l}\text { Working } \\
\text { concentration }\end{array}$ & $\begin{array}{l}\text { Secondary } \\
\text { antibody }^{2}\end{array}$ \\
\hline CD4 T cell & GC50A1 & IgM & $14 \mu \mathrm{g} / \mathrm{mL}$ & $\alpha$ IgM-FITC \\
\hline CD8 T cell & CACT80C & $\mathrm{IgG}_{1}$ & $14 \mu \mathrm{g} / \mathrm{mL}$ & $\alpha$ IgG $_{1}$-FITC \\
\hline$\gamma \delta \mathrm{TCR}^{+} \mathrm{T}$ cell & CACT61A & IgM & $14 \mu \mathrm{g} / \mathrm{mL}$ & $\alpha$ IgM-PE \\
\hline B cell & BAQ155A & $\operatorname{IgG}_{1}$ & $3.5 \mu \mathrm{g} / \mathrm{mL}$ & $\alpha$ IgG $_{1}-$ FITC \\
\hline Monocyte & BAQ151A & $\mathrm{IgG}_{1}$ & $3.5 \mu \mathrm{g} / \mathrm{mL}$ & $\alpha$ IgG $_{1}$-FITC \\
\hline MHC class II antigen $^{3}$ & TH14B & $\operatorname{IgG}_{2 \mathrm{a}}$ & $3.5 \mu \mathrm{g} / \mathrm{mL}$ & $\alpha \mathrm{IgG}_{2}-\mathrm{PE}$ \\
\hline IL-2 receptor & CACT108A & $\operatorname{IgG}_{2 \mathrm{a}}$ & $20 \mu \mathrm{g} / \mathrm{mL}$ & $\alpha \mathrm{IgG}_{2}-\mathrm{PE}$ \\
\hline
\end{tabular}

${ }^{1}$ Primary antibodies were from VMRD, Pullman, WA.

${ }^{2}$ FITC $=$ Fluorescein isothiocyanate, $\mathrm{PE}=$ phycoerythrin; FITC- and PE-conjugated secondary antibodies were from Southern Biotechnology Associates, Birmingham, Alabama, and were used at a dilution of 1:200 (5 $\mu \mathrm{L} / \mathrm{mL})$.

${ }^{3} \mathrm{MHC}=$ Major histocompatibility complex.

At 1 and 7 wk of age, 6 calves were vaccinated subcutaneously in the right midcervical region with $10^{7} \mathrm{cfu}$ of $M$. bovis BCG. Four young adults were vaccinated at the same times and served as controls for effects of maturity on the adaptive immune response. Six agematched calves were not vaccinated and served as negative controls for the effect of vaccination in the young calf.

\section{Blood Collection and Peripheral Blood Mononuclear Cell Isolation}

Peripheral blood was collected from each calf immediately before primary vaccination (1 wk of age) and again at wk $2,5,6,7,8$, and 11 (12 wk of age) after primary vaccination. Fifty milliliters of blood was taken from each side of the neck by jugular venipuncture. Blood was collected into $10 \%$ (vol/vol) $2 \times$ acid-citrate-dextrose [a sterilized solution containing sodium citrate $(77 \mu M)$, citric acid $(38 \mu M)$, and dextrose $(122 \mu M)]$. Smaller, anticoagulated (with potassium EDTA) and coagulated (no additive) blood samples were collected into 10-mL vacutainers (Becton Dickinson, Franklin Lakes, NJ). Harvested serum was frozen $\left(-20^{\circ} \mathrm{C}\right)$ until needed. Adults were bled on the same days in an identical fashion.

Peripheral blood mononuclear cells (PBMC) used in functional assays were isolated and enriched by density gradient centrifugation as described previously (Nonnecke et al., 1991). Contaminating erythrocytes were eliminated by hypotonic lysis before density gradient centrifugation of buffy-coat cells. Mononuclear cell-enriched populations were resuspended in RPMI 1640 medium (Gibco Laboratories, Grand Island, NY) supplemented with $2 \mathrm{mM}$ L-glutamine (Sigma Chemical Co.), antibiotics (100 U/mL of penicillin G and $100 \mu \mathrm{g} /$ $\mathrm{mL}$ of streptomycin sulfate), and antimycotics $(0.25 \mathrm{mg} /$ $\mathrm{mL}$ of amphotericin B; Gibco Laboratories). Nonessen- tial amino acids (Sigma Chemical Co.) and 2-mercaptoethanol ( $55 \mu M$, Gibco Laboratories) were added to this medium for cytokine assays.

\section{Analysis of Composition of PBMC Population}

Leukocytes in PBMC populations collected at wk 0 , $2,5,6,7,8$, and 11 after primary vaccination were phenotyped using a flow cytometry procedure described previously (Nonnecke et al., 1993). Briefly, buffy-coat cells were washed with and resuspended in PBS containing $0.02 \% \mathrm{NaN}_{3}$ and $1 \%$ (vol/vol) heat-inactivated fetal bovine serum (FBS, Hyclone Laboratories, Inc., Logan, UT). Approximately $5 \times 10^{5}$ cells in $100 \mu \mathrm{L}$ were added to each of 8 wells of a 96 -well round-bottom microtiter plate (Costar, Cambridge, MA) to determine phenotype. Individual wells were preloaded with a $50-\mu \mathrm{L}$ aliquot of monoclonal antibody (Table 1) diluted in PBS containing $0.02 \% \mathrm{NaN}_{3}$ and $1 \%$ inactivated FBS. Cells were incubated for $15 \mathrm{~min}$ at room temperature in the dark and the plate was centrifuged $(400 \times g$ for 2 min at room temperature). Supernatant was decanted and cells were resuspended in $100 \mu \mathrm{L}$ of each of 2 isotypespecific antibodies conjugated to the listed fluorochromes (Table 1). The antibodies were diluted in PBS containing $0.02 \% \mathrm{NaN}_{3}$ and $1 \%$ inactivated FBS (Table 1). Incubation and centrifugation steps were repeated as described above. Cells were resuspended in $200 \mu \mathrm{L}$ of FACS lysing solution (diluted 1:10; Becton Dickinson, San Jose, CA) and stored in the dark at $4^{\circ} \mathrm{C}$ until examined on the flow cytometer. Five thousand cells exhibiting light-scattering properties consistent with bovine PBMC were analyzed. Markers were positioned for negative control samples to provide a background of $\sim 2 \%$ and were maintained at this position for all samples. Data were acquired and analyzed using a FACScan flow cytometer and CellQuest software (Becton Dickinson). Variables recorded for each marker were percentages 
of cells that stained positive. These data in combination with total numbers of circulating leukocytes were used to estimate the number of cells positive for each marker.

\section{Recall Antigens}

Recall antigens used included $M$. avium-derived PPD (PPDa, CSL Ltd.), $M$. bovis-derived PPD (PPDb, CSL Ltd.), and a proteinase K-digested whole cell sonicate of M. bovis BCG (WCS-PK). The WCS-PK antigen, used as capture antigen in ELISA, was prepared from 2-wk $M$. bovis BCG cultures grown in Middlebrook's $7 \mathrm{H} 9$ media supplemented with $10 \%$ oleic acid-albumin-dextrose complex. Bacilli were pelleted, sonicated in PBS, and further disrupted with 0.1- to 0.15-mm glass beads (Biospec Products, Bartlesville, OK) in a bead-beater (Biospec Products) on ice. The preparation was centrifuged and the supernatant harvested and filtered $(0.22$ $\mu \mathrm{m})$. The whole cell sonicate was digested in $1 \mathrm{mg} / \mathrm{mL}$ proteinase $\mathrm{K}$ (50 $\mathrm{m} M$ Tris, $1 \mathrm{~m} M \mathrm{CaCl}_{2}$ buffer, $\mathrm{pH}$ 8.0; Roche Molecular Biochemicals, Indianapolis, IN) for 1 $\mathrm{h}$ at $50^{\circ} \mathrm{C}$. Protein concentration of WCS-PK antigen was determined using a kit provided by Bio-Rad (Hercules, CA). The WCS-PK antigen was stored at $-20^{\circ} \mathrm{C}$.

\section{DNA Synthesis by PBMC}

Mitogen- and antigen-induced DNA synthesis by PBMC was performed as reported previously (Nonnecke et al., 1991). Cells were from blood samples collected wk $0,2,5,6,7,8$, and 11 after primary vaccination. Briefly, cultures were established in flat-bottomed, 96-well tissue culture plates (Costar) inoculated with $1.0 \times 10^{6} \mathrm{PBMC} / \mathrm{mL}$ in a total volume of $200 \mu \mathrm{L}$. All cultures contained 5\% (vol/vol) FBS (Hyclone Laboratories, Inc.). Synthesis of DNA by PBMC was assessed in nonstimulated (resting) cultures and cultures stimulated with pokeweed mitogen (PWM, Sigma Chemical Co.) at $1 \mu \mathrm{g} / \mathrm{mL}$, or PPDb at $10 \mu \mathrm{g} / \mathrm{mL}$. Mitogen-stimulated cultures and associated nonstimulated cultures were incubated for $66 \mathrm{~h}$, and antigen-stimulated cultures were incubated for $144 \mathrm{~h}$. Cultures were prepared in triplicate and incubated at $39^{\circ} \mathrm{C}$ in a humidified atmosphere of $5 \% \mathrm{CO}_{2}$. Cultures were pulsed with 18.5 $\mathrm{kBq}$ of [methyl- ${ }^{3} \mathrm{H}$ ]-thymidine (Amersham Corp., Arlington Heights, IL) in $50 \mu \mathrm{L}$ of RPMI 1640 medium during the last $18 \mathrm{~h}$ of the incubation period. Cells were harvested onto glass fiber filters (model PHD cell harvester, Cambridge Technology, Watertown, MA) and retained radioactivity was measured by liquid scintillation spectrophotometry (LS8000 liquid scintillation counter, Beckman Instruments, Fullerton, CA). Synthesis of DNA by resting and stimulated cells was expressed in counts per minute.

\section{Proliferation of Lymphocyte Subsets}

Staining of PBMC with PKH67 was performed according to manufacturer instructions (Sigma Chemical Co.) and as described previously (Waters et al., 2003c). Cells were from blood samples collected at wk 5 after primary vaccination. Briefly, $2 \times 10^{7} \mathrm{PBMC}$ were centrifuged (10 min, $400 \times g)$, supernatants aspirated, and cells resuspended in $1 \mathrm{~mL}$ of diluent provided in the PKH67 kit. Cells in diluent were added to $1 \mathrm{~mL}$ of PKH67 green fluorescent dye $(2 \mu M)$ and incubated for 5 min followed by a 1-min incubation with $2 \mathrm{~mL}$ of FBS to adsorb the excess dye and stop further dye uptake by cells. Cells were then washed twice with RPMI 1640 medium and wells of 96 -well round-bottom plates (Falcon; Becton-Dickinson, Lincoln Park, NJ) were seeded with $2 \times 10^{5}$ PKH67-stained mononuclear cells in a total volume of $200 \mu \mathrm{L}$ per well ( 6 replicates/treatment). Cells were nonstimulated, stimulated with PWM $(1 \mu \mathrm{g} / \mathrm{mL})$, or PPDb $(10 \mu \mathrm{g} / \mathrm{mL})$, and incubated for $5 \mathrm{~d}$ at $37^{\circ} \mathrm{C}$ in a humidified atmosphere with $5 \% \mathrm{CO}_{2}$. Modfit Proliferation Wizard (Verity Software House Inc., Topsham, ME) was used for cell proliferation analyses. Proliferation profiles were determined for gated (i.e., $\mathrm{CD} 4^{+}$, $\mathrm{CD}^{+}$, or $\gamma \delta \mathrm{TCR}^{+}$) and ungated (total PBMC) populations. Data are presented as the mean $( \pm \mathrm{SEM})$ number of cells that had proliferated/10,000 PBMC.

\section{Cytokine and Nitric Oxide Secretion}

Cells used in cytokine assays were from blood samples collected at wk $0,2,6,8$, and 11 after primary vaccination. Cell suspensions were adjusted to an inassay concentration of $1 \times 10^{6} \mathrm{cell} / \mathrm{s} / \mathrm{mL}$. Duplicate cultures were nonstimulated or stimulated with PWM (1 $\mu \mathrm{g} / \mathrm{mL})$ or PPDb (10 $\mu \mathrm{g} / \mathrm{mL})$ and were incubated 24,48 , and $72 \mathrm{~h}$ in a humidified atmosphere containing 5\% $\mathrm{CO}_{2}$. Supernatants were subsequently harvested from centrifuged plates $(400 \times g, 5 \mathrm{~min}$, room temperature) and stored at $-80^{\circ} \mathrm{C}$ until analysis.

Interferon- $\gamma$ was measured using a capture ELISA (protocol and reagents generously provided by L. Babiuk, Veterinary Infectious Diseases Organization, Saskatoon, Saskatchewan, Canada). Assays were performed in Immunolon II microtiter plates (Dynatech Laboratories, Inc., Chantilly, VA). Reagents consisted of a capture antibody (mouse antirBoIFN- $\gamma$, IgG fraction, lot TB-4-91), detection antibody (rabbit antibovine IFN- $\gamma$, IgG fraction, lot 90-81), rBoIFN- $\gamma$ (lot TB-4-91), biotinylated goat antirabbit IgG (Zymed Laboratories, Inc., South San Francisco, CA), horseradish peroxidaseconjugated streptavidin-biotinylated complex (Amersham Corporation, Arlington Heights, IL), and substrate/indicator $\left(\mathrm{H}_{2} \mathrm{O}_{2}\right.$ and 2,2'-azinodi-ethylbenzothiazoline-sulfonic acid in citrate buffer). Internal stan- 
dards consisted of serially diluted $\mathrm{rBoIFN}^{-} \gamma$ in PBS with Tween $80(0.1 \% \mathrm{vol} / \mathrm{vol})($ PBST) and with gelatin $(0.1 \% \mathrm{vol} / \mathrm{vol})$ (PBST-g). Positive and negative control samples and test samples were serially diluted in PBST-g. Capture antibody was in carbonate coating buffer, and detection antibody was diluted in PBST-g. Biotinylated goat antirabbit Ig and horseradish peroxidase-conjugated streptavidin-biotinylated complex were diluted in PBST without gelatin. Intervening washes were done with PBST without gelatin. All incubations were at room temperature with the exception of capture antibody in carbonate buffer, which was incubated for $3 \mathrm{~d}$ or less at $4^{\circ} \mathrm{C}$. Absorbances of standards and test samples were read at 405 to $490 \mathrm{~nm}$ using an automated ELISA plate-washer and reader (Dynatech MR7000, Dynatech Laboratories Inc., Guernsey, UK). Concentrations of IFN- $\gamma$ in test samples were determined by comparing the absorbances of test samples with the absorbances of standards within a linear curve fit. Mean IFN- $\gamma$ concentrations (ng/mL) produced in 48and 72-h cultures are presented.

Tumor necrosis factor (TNF)- $\alpha$ was measured using a capture ELISA (protocol and reagents provided by L. Babiuk, Veterinary Infectious Diseases Organization, Saskatoon, Saskatchewan, Canada). Assays were performed in Immunolon II microtiter plates (Dynatech Laboratories, Inc.). Reagents consisted of a capture antibody (mouse ascites antiTNF, IgG fraction), detection antibody (rabbit antibovine-TNF- $\alpha$, IgG fraction), rBoTNF- $\alpha$, biotinylated goat antirabbit IgG (Zymed Laboratories, Inc.), horseradish peroxidase-conjugated streptavidin-biotinylated complex (Amersham Corp.), substrate $\left(\mathrm{H}_{2} \mathrm{O}_{2}\right.$ at $\left.0.1 \% \mathrm{vol} / \mathrm{vol}\right)$, and dye (2,2'-azinodiethylbenzothiazoline-sulfonic acid). Internal standards of serially diluted rBoTNF- $\alpha$ were prepared in PBST. Positive and negative controls and test samples also were diluted serially in PBST-g. Capture antibody was diluted in carbonate buffer ( $\mathrm{pH}$ 9.6, $0.01 \mathrm{M}$ ), and detection antibody in PBST-g. Biotinylated goat antirabbit Ig and horseradish peroxidase-conjugated streptavidinbiotinylated were diluted in PBST without gelatin. Intervening washes used PBST without gelatin. Enzyme substrate and indicator were dye diluted in citrate buffer. All incubations were at room temperature with the exception of capture antibody in carbonate buffer, which was incubated at $4^{\circ} \mathrm{C}$. Absorbances of standards and test samples were read at 405 and $490 \mathrm{~nm}$ using an ELISA plate-washer and reader (Dynatech Laboratories, Inc.). Cytokine concentrations $(\mathrm{ng} / \mathrm{mL})$ in test samples were determined by comparing absorbances of test samples with absorbances of standards within a linear curve fit. Mean TNF- $\alpha$ concentrations ( $\mathrm{ng} / \mathrm{mL}$ ) produced in 48- and 72-h cultures are presented.
Production of inducible NO by PBMC was assayed in flat-bottom, 96-well tissue culture plates inoculated with $4 \times 10^{6}$ cells $/ \mathrm{mL}$ in a final volume of $200 \mu \mathrm{L}$ as described previously (Rajaraman et al., 1998). Duplicate cultures were nonstimulated, stimulated with PWM $(1 \mu \mathrm{g} / \mathrm{mL})$, or stimulated with PPDb $(10 \mu \mathrm{g} / \mathrm{mL})$ in RPMI 1640 medium. Plates were incubated for 24, 48 , and $72 \mathrm{~h}$ at $39^{\circ} \mathrm{C}$ in a humidified atmosphere with $5 \% \mathrm{CO}_{2}$. Culture supernatants were harvested after centrifuging plates $\left(400 \times g, 21^{\circ} \mathrm{C}, 5 \mathrm{~min}\right)$.

Nitrite is the stable oxidation product of $\mathrm{NO}$ and its presence in culture supernatants correlates with the amount of NO produced. Concentrations of stable nitrite in supernatants were assayed as described previously (Rajaraman et al., 1998). Briefly, the assay was performed in microtiter plates (Immunolon II; Dynatech Laboratories, Inc.). Culture supernatant (100 $\mu \mathrm{L})$ was mixed with $100 \mu \mathrm{L}$ of Griess reagent $(0.5 \%$ sulfanilamide; Sigma Chemical Co.) in 2.5\% phosphoric acid (Mallinckrodt Chemicals, Inc., Paris, KY) and 0.05\% N(1-naphthyl) ethylenediamine dihydrochloride (Sigma Chemical Co.). The mixture was incubated at $21^{\circ} \mathrm{C}$ for $10 \mathrm{~min}$. Absorbances of test and standard wells were measured at $570 \mathrm{~nm}$ using an ELISA plate reader (Dynatech Laboratories, Inc.). All dilutions were made using culture medium (RPMI 1640 with $2 \mathrm{mM}$ L-glutamine and 5\% vol/vol FBS). Absorbances of test samples were converted to micromoles of nitrite by comparison with absorbances of sodium nitrite standards (Fisher Chemicals, Fair Lawn, NJ) within a linear curve fit. The concentration of nitrite $(\mu M)$ in supernatants was calculated by multiplying the value from the standard curve by the dilution factor. $\mathrm{N}^{\mathrm{G}}$-Monomethyl-L-arginine, a competitive inhibitor of the enzyme, inducible NO synthase, was used as a negative control. The inhibitor $(1.15 \mathrm{~m} M$, equimolar to the amount of L-arginine in the culture medium; Calbiochem, La Jolla, CA) was added to parallel nonstimulated or stimulated cultures to verify that the nitrite produced was a result of the specific activity of inducible NO synthase.

\section{Cutaneous Delayed-Type Hypersensitivity Reaction}

Eleven weeks after primary vaccination, antigen-specific recall responses of young adults and 12-wk-old calves were evaluated in vivo using a comparative cervical skin test. Briefly, the cervical region was clipped and animals were injected intradermally with $100 \mu \mathrm{L}$ each of PPDa and PPDb $(1 \mathrm{mg} / \mathrm{mL})$. Skin-fold thickness $(\mathrm{mm})$ was measured immediately before and $72 \mathrm{~h}$ after administration of antigens. Results are expressed as the differences between these values. 


\section{Measurement of Antibody in Serum and in Culture Supernatants}

Antigen-specific IgG concentrations were determined for serum samples collected $0,6,7$, and 11 wk after primary vaccination. Antibody levels in supernatants from nonstimulated PBMC cultures and cultures stimulated with mitogen or antigen were evaluated. Cells were from blood samples collected 6 wk after primary vaccination. Using 96 -well microtiter plates, duplicate cultures were seeded with $2 \times 10^{6}$ cells $/ \mathrm{mL}$ and were nonstimulated, stimulated with PWM $(1 \mu \mathrm{g} / \mathrm{mL})$, or stimulated with PPDb $(10 \mu \mathrm{g} / \mathrm{mL})$. Cultures were incubated for $8 \mathrm{~d}$ at $39^{\circ} \mathrm{C}$ in a humidified atmosphere with $5 \% \mathrm{CO}_{2}$. Supernatants from centrifuged $\left(400 \times g, 21^{\circ} \mathrm{C}\right.$, 5 min) plates were stored at $-80^{\circ} \mathrm{C}$ until analyzed.

The relative amount of antibody to lipoarabinomannan-enriched mycobacterial antigen (i.e., WCS-PK) in serum and in culture supernatants was determined by a capture ELISA. The concentration of WCS-PK used in the ELISA was $40 \mu \mathrm{g} / \mathrm{mL}$. Microtiter plates (96-well; Immunolon II, Dynatech) were coated with antigen (100 $\mu \mathrm{L} /$ well) diluted in carbonate/bicarbonate coating buffer ( $\mathrm{pH}$ 9.6). Plates, including control wells containing coating buffer alone, were incubated for $15 \mathrm{~h}$ at $4^{\circ} \mathrm{C}$. Plates were washed $3 \times$ with PBST $(200 \mu \mathrm{L} /$ well of $0.05 \%$ Tween 20), and blocked with a commercial milk diluent/blocking solution $(200 \mu \mathrm{L} /$ well; Kirkegaard and Perry Laboratories, Gaithersburg, MD). After incubation for $1 \mathrm{~h}$ at $37^{\circ} \mathrm{C}$ in the blocking solution, wells were washed in PBST, and test sera were added to wells (100 $\mu \mathrm{L} /$ well). Test and control sera were diluted in PBS containing $0.1 \%$ gelatin. Optimal dilutions of test sera were determined by evaluation of the reactivity of 2-fold serial dilutions ranging from 1:6 to 1:800 (31). Supernatants were not diluted. After incubating for $20 \mathrm{~h}$ at $4^{\circ} \mathrm{C}$ with test samples, wells were washed with PBST and incubated for $1 \mathrm{~h}$ at $37^{\circ} \mathrm{C}$ with horseradish peroxidase-conjugated antibovine IgG heavy and light chains (Kirkegaard and Perry Laboratories) in PBS plus $0.1 \%$ gelatin. Wells were then washed with PBST and incubated for $4.5 \mathrm{~min}$ at room temperature with substrate (3,3' 5,5'-tetramethylbenzidine; Kirkegaard and Perry Laboratories). The reaction was stopped by addition of sulfuric acid $(0.18 M)$ and absorbances $(450 \mathrm{~nm})$ of individual wells were measured using an ELISA plate reader (Molecular Devices, Menlo Park, CA). The change in optical density readings was calculated by subtracting the mean optical density readings for wells receiving coating buffer alone ( 2 replicates) from the mean optical density readings for antigencoated wells (2 replicates) receiving the same test sample.

\section{Statistical Analysis}

Data were assessed for normality before statistical analysis. Arithmetic and $\log _{10}$-transformed data were analyzed as a split-plot with repeated measures ANOVA using Statview software (version 5.0, SAS Institute, Inc., Cary, NC). The model included effects of treatment (i.e., vaccination and animal maturity), time (days on trial), and the interaction of treatments and time on growth, health variables, composition of PBMC populations, and function of PBMC populations ex vivo. Fisher's protected-LSD test was applied when significant effects $(P<0.05)$ were detected by the model.

\section{RESULTS}

\section{Growth Performance and Health of Calves}

Growth performance was not affected $(P=0.87)$ by vaccination. Weights of all calves at $1 \mathrm{wk}$ of age (at the beginning of the study) averaged $49.6 \mathrm{~kg}$ and increased progressively $(P<0.0001)$ during the study period. At $12 \mathrm{wk}$ of age, calf weight averaged $117.3 \mathrm{~kg}$. Several subjective measurements of health were recorded on a regular basis during the experimental period. These included scour and respiration scores, cost of electrolytes, DM intake, and body size (hip height, body length, heart girth, and hip width). These variables were unaffected $(P>0.05)$ by vaccination (data not shown).

\section{Composition of PBMC Populations}

Calves and young adults were vaccinated at the beginning of the study and 6 wk later. Total numbers of leukocytes (mononuclear cells and granulocytes) in peripheral blood of calves were unaffected by vaccination $(P>0.05)$ (data not shown). Relative contributions of the various cell-types comprising PBMC populations from calves and heifers are shown in Figure 1. The composition of calf PBMC populations was unaffected by vaccination $(P>0.05)$. Percentages of several cell types comprising this population, however, were influenced by animal maturity. These included B cells (Figure 1a, $P<0.001$ ), $\gamma \delta \mathrm{TCR}^{+}$cells (Figure $1 \mathrm{~b}, P<0.01$ ), and $\mathrm{CD}^{+}$cells (Figure 1c, $P<0.01$ ). Percentages of circulating $\mathrm{B}$ cells and $\mathrm{CD} 8^{+} \mathrm{T}$ cells in 1-wk-old calves were lower $(P<0.05)$ than percentages in heifers, whereas $\gamma \delta \mathrm{TCR}^{+}$cell percentages were higher $(P<$ 0.05). At 12 wk of age, compositional differences between calf and adult PBMC populations were not significant $(P>0.05)$. Percentages of $\mathrm{CD}^{+}, \mathrm{CD}^{+}$, major histocompatibility class $\mathrm{II}^{+}$, IL-2 receptor ${ }^{+}$cells, and monocytes in calf and heifer PBMC populations were not different $(P>0.05)$ throughout the experimental period (data not shown). 


\section{Mitogen- and Antigen-Induced DNA Synthesis and Cell Proliferation}

General responsiveness of PBMC populations from calves and heifers to polyclonal and antigen stimulation was evaluated in a DNA synthesis (blastogenesis) assay (Figure 2) and a flow cytometry-based, cell-proliferation assay (Figure 3). Rates of thymidine incorporation by PWM-stimulated calf and adult PBMC were comparable and substantially greater $(P<0.001)$ than incorporation rates in parallel, nonstimulated cultures (Figure 2a). Although responses of cells from vaccinated calves and young adults were greater than responses of cells from nonvaccinated calves to antigen (PPDb), cells from vaccinated heifers responded more vigorously $(P<$ 0.001 ) to antigen than cells from vaccinated calves (Figure 2a). Longitudinal changes in PPDb-specific blastogenic responses of cells from calves and young adults are shown in Figure 2b. At the time of primary vaccination, responses of cells from all individuals to antigen (PPDb) were comparable and of low magnitude. Cells from nonvaccinated calves remained unresponsive to PPDb throughout the study period. In contrast, blastogenic responses of cells from vaccinated calves and young adults were greater than responses of nonvaccinates from wk 2 through 11 of the postvaccination period. From wk 2 through 8, PPDb-specific responses of vaccinated calves tended to be lower than responses of vaccinated young adults and by wk 11 were lower $(P$ $<0.01$ ).

Proliferative responses of the cells from nonvaccinated and vaccinated calves as well as vaccinated young adults to PWM and PPDb are shown in Figure 3. Cells were collected only once (at 6 wk after primary vaccination, $7 \mathrm{wk}$ of age). Pokeweed mitogen-induced proliferation of $\mathrm{CD}^{+}$and $\mathrm{CD}^{+} \mathrm{T}$ cells from calves and young adults was similar in magnitude. The $\gamma \delta \mathrm{TCR}^{+} \mathrm{T}$ cell subset and the PBMC population from vaccinated young adults, however, were more responsive $(P<$ 0.001 ) to mitogen than comparable populations from calves (Figure 3a). Antigen-induced (PPDb) proliferation of $\mathrm{CD}^{+}$and $\gamma \delta \mathrm{TCR}^{+} \mathrm{T}$ cells subsets and PBMC from vaccinated calves, in contrast, was comparable to proliferation of antigen-stimulated populations from vaccinated young adults and exceeded $(P<0.05)$ proliferative responses of cells from nonvaccinated calves (Figure $3 \mathrm{~b}$ ). Under the same conditions, proliferation of $\mathrm{CD} 8^{+} \mathrm{T}$ cells from vaccinates was comparable to responses of the same population from nonvaccinated calves and substantially less $(P<0.05)$ than responses of $\mathrm{CD}^{+}{ }^{+}$and $\gamma \delta \mathrm{TCR}^{+} \mathrm{T}$ cells from vaccinates to antigen.

\section{Mitogen- and Antigen-Induced IFN- $\gamma$, TNF- $\alpha$, and NO Secretion}

Antigen-induced secretion of IFN- $\gamma$ and NO by cells from sensitized individuals is essential for effective cell-

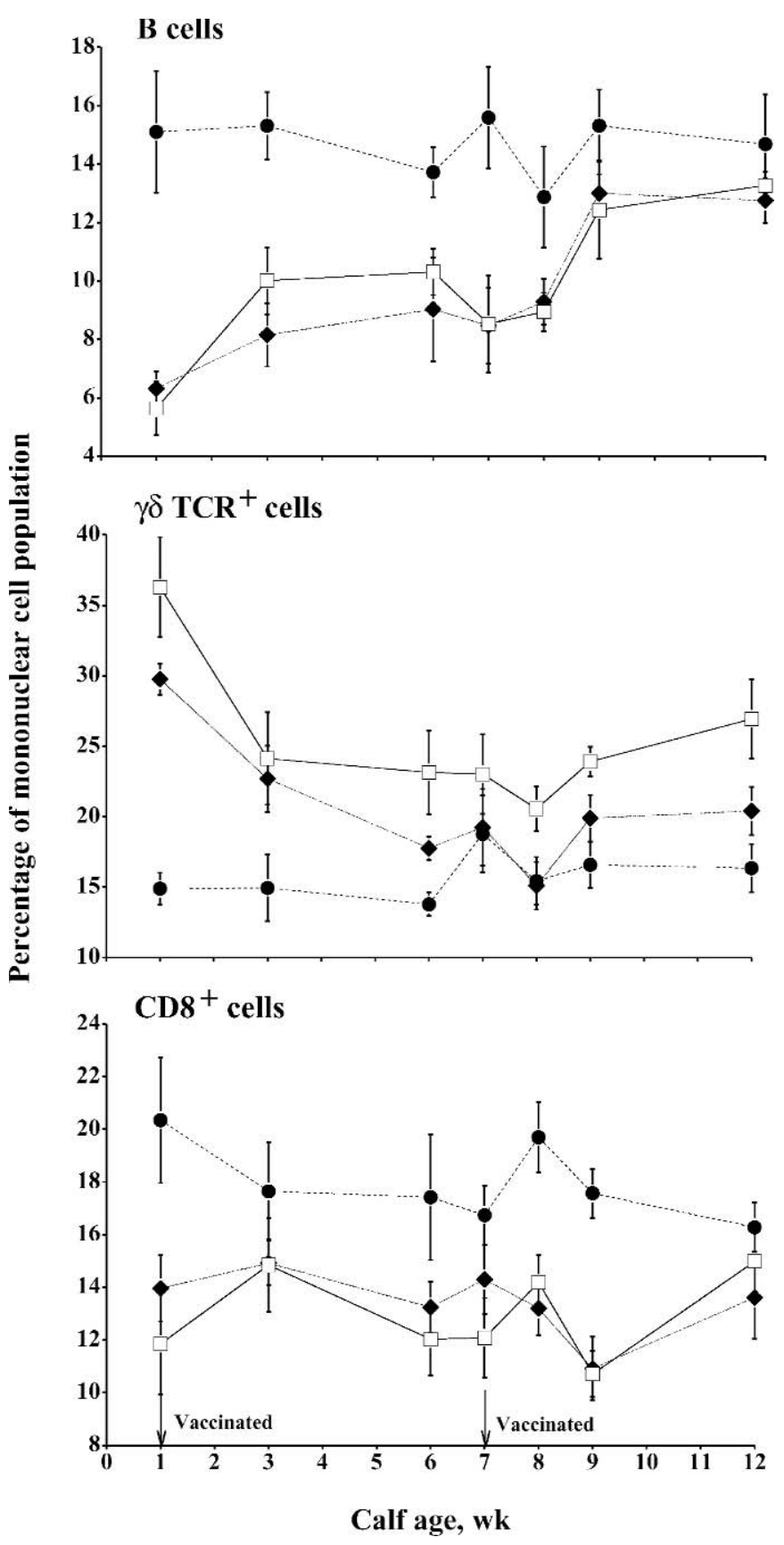

Figure 1. Composition of blood mononuclear cell populations from nonvaccinated calves $(-\square-, \mathrm{n}=6)$, vaccinated calves $(--, \mathrm{n}=6)$, and vaccinated young adults $(--, n=4)$. Calves were vaccinated at 1 and $7 \mathrm{wk}$ of age. Composition of cell populations was unaffected by vaccination. Cell types influenced $(P<0.05)$ by animal maturity are shown.

mediated immunity. Interferon- $\gamma$, TNF- $\alpha$, and NO secretion by mitogen- and antigen-stimulated cells from calves and young adults are shown in Figures 4, 5, and 6. Mitogen-induced IFN- $\gamma$ secretion by cells from calves and young adults was comparable and greater $(P<$ 

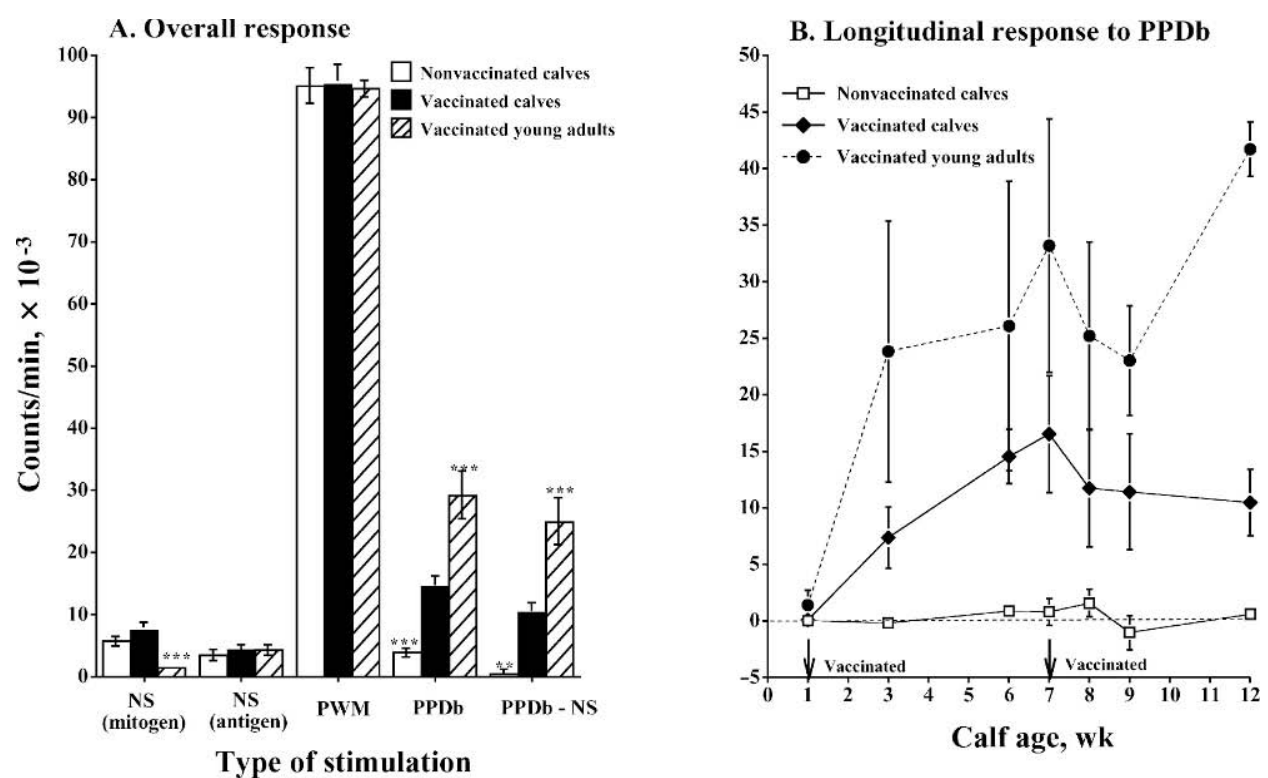

Figure 2. DNA synthesis by nonstimulated [NS (mitogen): 66-h incubation; NS (antigen): 144-h incubation], pokeweed mitogen-stimulated $(\mathrm{PWM})$ and purified protein derivative-stimulated $(\mathrm{PPD})$ blood mononuclear cells from nonvaccinated calves $(\mathrm{n}=6)$, vaccinated calves $(\mathrm{n}=$ 6 ), and vaccinated young adults $(\mathrm{n}=4)$. Calves were vaccinated at 1 and 7 wk of age. Blood samples were collected at wk $0,2,5,7,8$, and 11 after primary vaccination. Mean responses of nonstimulated and stimulated cells from nonvaccinates and vaccinates during postvaccination period are shown in panel A. Mean values were based on responses at wk 3, 6, 7, 8, 9, and 12 following primary vaccination. Responses of cells to antigen (PPD responses - nonstimulated responses) from 1 to $12 \mathrm{wk}$ of age are shown in panel B. Asterisks indicate responses of vaccinated calves that differed from responses of nonvaccinated calves or vaccinated young adults, $* * P<0.01, * * * P<0.001$.
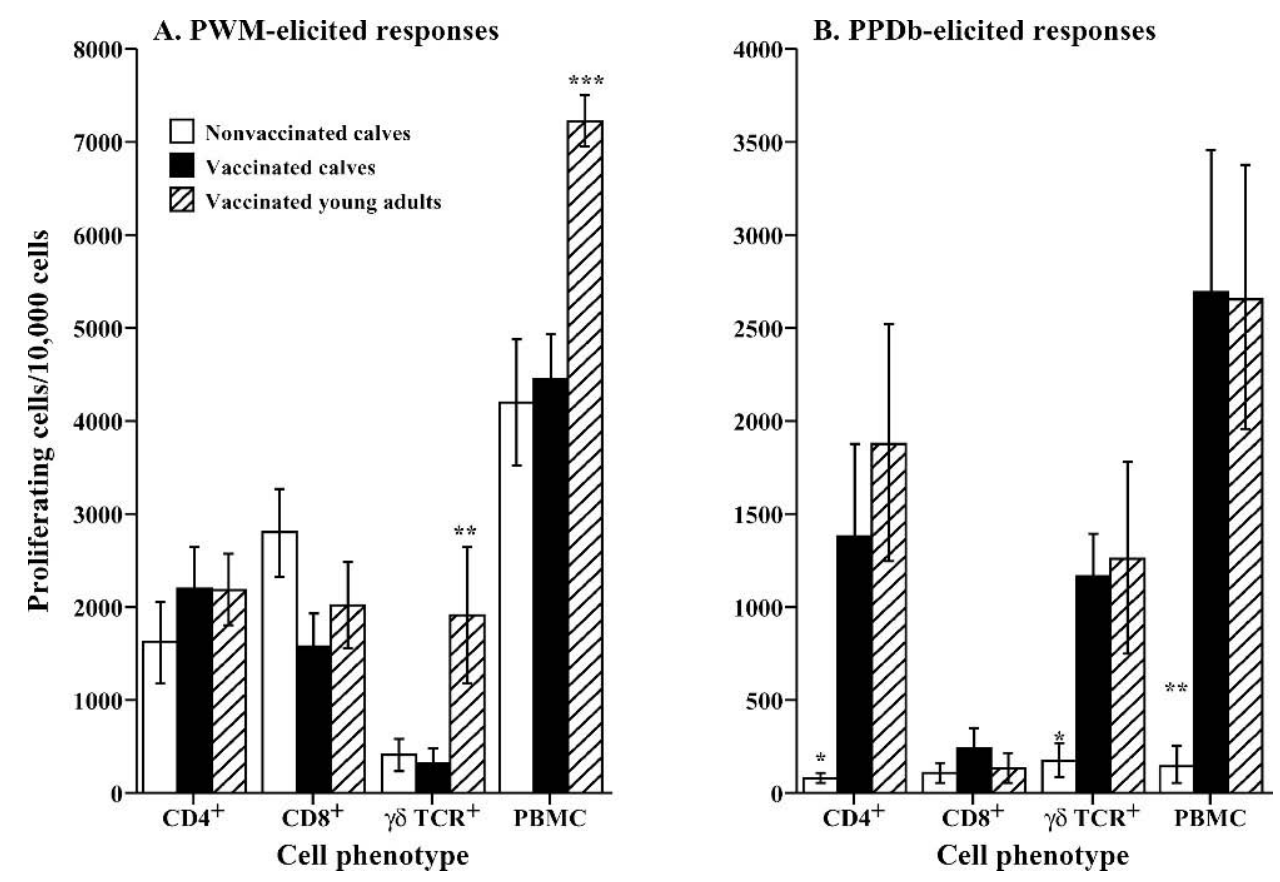

Figure 3. Proliferation of mitogen- (A) and antigen-stimulated (B) blood mononuclear cells from nonvaccinated calves ( $\mathrm{n}=6$ ), vaccinated calves $(n=6)$, and vaccinated young adults $(n=4)$. Calves were vaccinated at 1 and 7 wk of age. Cells were collected 7 wk after primary vaccination, stained with PKH67, and incubated in media alone (nonstimulated) or in medium containing pokeweed mitogen (PWM) or purified protein derivative (PPD). Values represent responses in mitogen- or antigen-stimulated cultures minus responses in resting (nonstimulated) cultures. Asterisks indicate proliferative responses of vaccinated calves that differed from responses of nonvaccinated calves or vaccinated young adults, $* * P<0.01, * * * P<0.001$. 



Figure 4. Interferon- $\gamma$ secretion by nonstimulated (NS), pokeweed mitogen-stimulated (PWM), and purified protein derivative-stimulated (PPD) blood mononuclear cells from nonvaccinated calves $(\mathrm{n}=$ $6)$, vaccinated $(n=6)$ calves, and vaccinated young adults $(n=4)$. Calves were vaccinated at 1 and 7 wk of age. Blood samples were collected at wk $0,2,6,8$, and 11 after primary vaccination. Mean responses of nonstimulated and stimulated cells from nonvaccinates and vaccinates during postvaccination period are shown in panel A. Mean values shown were based on responses at wk 3, 7, 9, and 12 following primary vaccination. Responses of cells to antigen (PPD responses - nonstimulated responses) from 1 to 12 wk of age are shown in panel B. Asterisks indicate responses in vaccinated calves that differed from responses of nonvaccinated calves or vaccinated young adults, ${ }^{* *} P<0.01, * * * P<0.001$.
0.001) than secretion by nonstimulated cells from the same individuals (Figure 4a). Antigen-induced IFN- $\gamma$ responses of cells from vaccinated calves were comparable to responses of cells from vaccinated young adults and exceeded $(P<0.001)$ responses of cells from nonvaccinated calves. Interestingly, PPDb-stimulated cells from nonvaccinated calves produced more IFN- $\gamma$ than nonstimulated cells from the same individuals $(P<$ 0.05).

Examination of longitudinal changes in IFN- $\gamma$ secretion by PPDb-stimulated cells from individuals in each treatment group indicated that all groups produced demonstrable amounts of IFN- $\gamma$ (Figure $4 \mathrm{~b})$. At the time of primary vaccination, responses of cells from all individuals to antigen (PPDb) were comparable and of low magnitude. Recall responses of vaccinated calves and young adults, however, were substantially greater than responses of nonvaccinated heifers from wk 2 through 11. Responses of cells from vaccinated calves exceeded responses of vaccinated adults $6 \mathrm{wk}$ after primary vaccination $(P<0.05)$.

Secretion of TNF- $\alpha$ by mitogen- and antigen-stimulated cells from nonvaccinated calves, vaccinated calves, and vaccinated young adults is shown in Figure 5. Mitogen-induced secretion by cells from vaccinated calves was comparable to secretion by vaccinated young adults but greater $(P<0.01)$ than amounts secreted by nonvaccinated calves (Figure 5a). Mitogen-stimulated cells produced substantially more TNF- $\alpha$ than nonstimulated or PPDb stimulated cells regardless of donor animal treatment. Recall responses of vaccinated calves were greater than responses of vaccinated young adults $(P<0.05)$ and nonvaccinated calves $(P<0.001)$. Overall responses of nonstimulated and PPDb-stimulated cells from nonvaccinates were not different $(P=0.95)$.

Longitudinal changes in TNF- $\alpha$ production in PPDbstimulated cell cultures are shown in Figure 6b. At the time of primary vaccination, the response of cells from nonvaccinated calves to PPDb was greater $(P<0.05)$ than responses of cells from vaccinated calves and young adults. With the exception of the response of vaccinated young adults at wk 8 after primary vaccination, responses of vaccinated calves and adults exceeded the response of nonvaccinated calves during the study period. Two weeks after primary vaccination, the recall response of vaccinated calves ( 3 wk of age) was substantially greater than the recall response of vaccinated young adults $(P<0.01)$.

Nitrite production by mitogen- and antigen-stimulated cells from nonvaccinated calves, and vaccinated calves and adults is shown in Figure 6. Responses of cells from vaccinated calves to PWM exceeded responses of cells from vaccinated young adults $(P<0.05)$ and tended to be greater than responses of cells from 

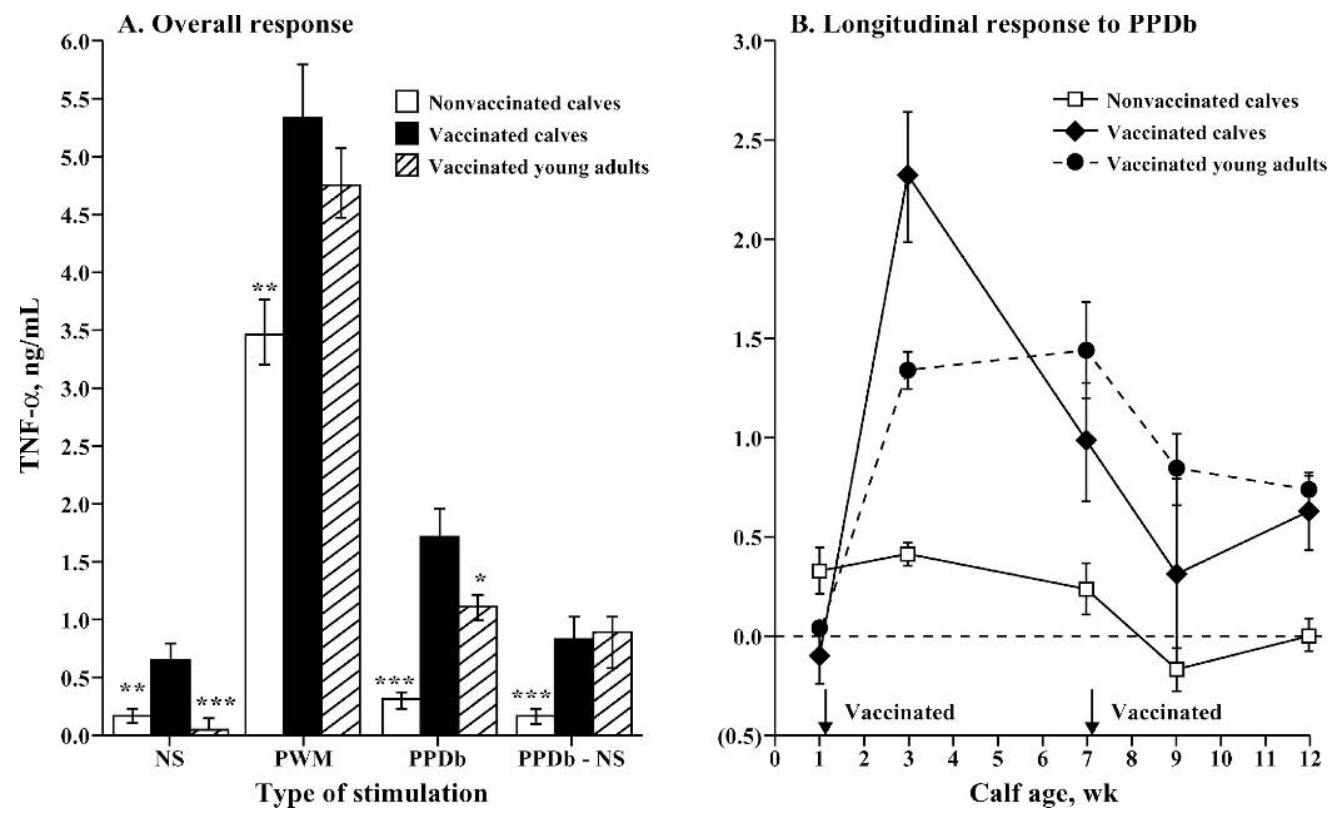

Figure 5. Tumor necrosis factor- $\alpha$ (TNF- $\alpha$ ) secretion by nonstimulated (NS), pokeweed mitogen-stimulated (PWM), and purified protein derivative-stimulated (PPD) blood mononuclear cells from nonvaccinated calves $(n=6)$, vaccinated $(n=6)$ calves, and vaccinated young adults $(\mathrm{n}=4)$. Calves were vaccinated at 1 and $7 \mathrm{wk}$ of age. Blood samples were collected at wk $0,2,6,8$, and 11 after primary vaccination. Mean responses of nonstimulated and stimulated cells from nonvaccinates and vaccinates during postvaccination period are shown in panel A. Mean values shown were based on responses at wk 3, 7, 9, and 12 following primary vaccination. Antigen-induced (PPD responses nonstimulated responses) responses of cell populations from 1 to $12 \mathrm{wk}$ of age are shown in panel B. Asterisks indicate responses of vaccinated calves that differed from responses of nonvaccinated calves or vaccinated young adults, $* * P<0.01, * * * P<0.001$.


Figure 6. Nitric oxide production by nonstimulated (NS), pokeweed mitogen-stimulated (PWM), and purified protein derivative-stimulated (PPD) blood mononuclear cells from nonvaccinated $(n=6)$, vaccinated $(n=6)$ calves, and vaccinated heifers $(n=4)$. Calves were vaccinated at 1 and 7 wk of age. Blood samples were collected at wk $0,2,6$, 8, and 11 after primary vaccination. Mean responses of nonstimulated and stimulated cells from nonvaccinates and vaccinates during postvaccination period are shown in panel A. Mean values shown were based on responses at wk 3, 7, 9, and 12 following primary vaccination. Responses of cells to antigens (PPD responses - nonstimulated responses) from 1 to $12 \mathrm{wk}$ of age are shown in panel B. Asterisks indicate responses of vaccinated calves that differed from responses of nonvaccinated calves or vaccinated young adults, $* * P<0.01, * * * P<0.001$. 
nonvaccinated calves $(P=0.07)$ (Figure 6a). Nitrite production by cells from vaccinated calves to antigen (PPDb) exceeded production by cells from vaccinated young adults $(P<0.05)$. The amount of nitrite produced by PPDb-stimulated cells from nonvaccinated calves was comparable to amounts produced by nonstimulated (i.e., resting), autologous cells and substantially less ( $P$ $<0.001)$ than amounts produced by PPDb-stimulated cells from vaccinates.

Longitudinal changes in nitrite production in PPDbstimulated cell cultures are shown in Figure 6b. Responses of cells from all individuals to PPDb were comparable and of low magnitude immediately before primary vaccination. From wk 2 through 11 after primary vaccination, cells from vaccinates (calves and young adults) produced substantially more nitrite than cells from nonvaccinated calves. Nitrite secretion by cells from vaccinated calves and young adults was comparable during this period, however, responses of cells from vaccinated calves tended to be higher at the end of the study $(P=0.09)$. Interestingly, recall responses of vaccinates (calves and adults) decreased $(P<0.05)$ substantially following revaccination 6 wk after primary vaccination.

\section{Responses to Cervical Skin-Fold Test}

Results from the comparative cervical skin-fold test performed at the conclusion of the study (when calves were 12 wk old, wk 11 after primary vaccination) are shown in Figure 7. Nonvaccinated calves, vaccinated calves, and vaccinated young adults had demonstrable cutaneous responses to PPDa. The PPDa-elicited responses of vaccinated calves and young adults were not different but were substantially greater $(P<0.01)$ than the response of nonvaccinates to PPDa. Responses of the 3 treatment groups to PPDb followed a pattern similar to their responses to PPDa, although responses of vaccinates to $\mathrm{PPDb}$ exceeded $(P<0.05)$ their responses to cross-reactive antigen, PPDa. The mean response of vaccinated calves to $\mathrm{PPDb}$ was marginally greater $(P=0.17)$ than the mean response of vaccinated young adults and substantially greater $(P<0.001)$ than that of nonvaccinated calves.

\section{Antigen-Specific Ig Production}

An ELISA utilizing a lipoarabinomannan-enriched mycobacterial capture antigen was used to measure antibody in serum and in supernatants from PPDbstimulated PBMC cultures. Changes in relative amounts of antibody in the peripheral blood of calves as well as vaccinated young adults during the study period are shown in Figure 8a. At 1 wk of age and before

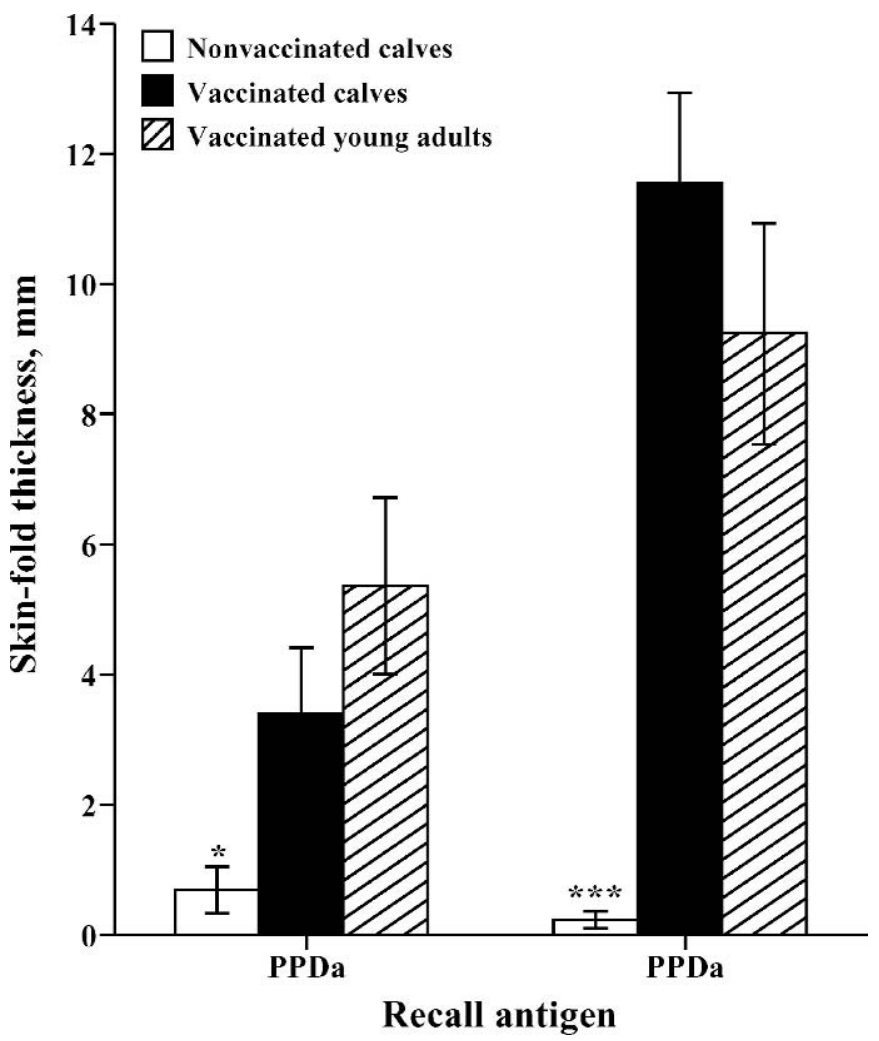

Figure 7. Cutaneous delayed-type hypersensitivity reactions in nonvaccinated calves $(n=6)$, vaccinated calves $(n=6)$, and vaccinated young adults $(\mathrm{n}=4)$ at $11 \mathrm{wk}$ after primary vaccination. Antigens [Mycobacterium avium purified protein derivative (PPDa), and $M$. bovis PPD (PPDb)] were injected intradermally, and skin-fold thickness at the site was measured at 0 and $72 \mathrm{~h}$. Asterisks indicate responses (skin thickness at $72 \mathrm{~h}$ minus pretest thickness) of nonvaccinated calves that differed from vaccinated calves and vaccinated young adults, $* P<0.05$, **** $P<0.001$.

primary vaccination, calves had measurable amounts of antibody in their circulation, possibly reflecting presence of cross-reactive, maternal antibody acquired through the ingestion of colostrum. Antibody was not detectable (i.e., less than background measurement) in sera from vaccinated young adults at this time. Antibody in sera from vaccinated and nonvaccinated calves decreased progressively during the study period and was not detectable from 8 to $12 \mathrm{wk}$ of age. In contrast, vaccinated young adults manifested a pronounced increase in serum antibody at wk 9 and 11 after primary vaccination or wk 1 and 3 after the second BCG vaccination. Serum antibody levels in vaccinated young adults exceeded $(P<0.001)$ levels in nonvaccinated and vaccinated calves at wk 9 and 11 after primary vaccination.

Relative amounts of lipoarabinomannan-enriched mycobacterial antigen-specific Ig in supernatants from nonstimulated and PPDb-stimulated cell cultures are shown in Figure 8b. Cells were collected 6 wk after 



Figure 8. Relative amounts of antibody in sera from nonvaccinated calves $(n=6)$, vaccinated calves $(n=6)$, and vaccinated young adults $(n=4)$, and in supernatants from 8-d cultures of blood mononuclear cells from animals in each treatment group. Lipoarabinomannanenriched mycobacterial antigen was used in a capture ELISA. Calves were vaccinated at 1 and 7 wk of age. Serum was collected at the time of vaccination and at wk 6,7 , and 11 after primary vaccination. Supernatants were from cultures utilizing cells collected at wk 6 after primary vaccination. Data represent mean differences between test and background absorbance values. Asterisks indicate responses of vaccinated calves that differed from responses of nonvaccinated calves or vaccinated young adults, $* P<0.05$, $* * P<0.01$. primary vaccination, washed, and resuspended in medium with FBS. Nonstimulated cells from each group produced measurable amounts of antibody. Cells from nonvaccinated calves did not secrete measurable amounts of antibody when stimulated with PPDb. Antigen-stimulated cells from vaccinated calves secreted more $(P<0.05)$ antibody than cells from nonvaccinated calves but substantially less $(P<0.001)$ than cells from vaccinated young adults.

\section{DISCUSSION}

Development of the adaptive immune response after early vaccination (within the first week of life) has not been characterized extensively in dairy calves. The present study evaluated effects of immunization during the neonatal period on the adaptive immune response of calves and compared these responses to those of adult cattle vaccinated concurrently in an identical fashion. Calves vaccinated with BCG during the first week of life produced Th1-like responses to recall antigen that were similar to responses of vaccinated adult cattle. Responses indicative of the development of a cell-mediated immune (Th1) response were evident in vaccinated calves and adults by wk 2 postvaccination and persisted for the duration of the 11-wk study period. Buddle et al. (2003b) demonstrated that vaccinating the calf at birth or at 6 wk of age with BCG induces strong antigenspecific responses typical of cell-mediated immunity; however, responses of the calves and adult cattle were not compared. In the present study, vaccinated adults developed measurable antibody responses in vivo and ex vivo after the second BCG vaccination, whereas vaccinated calves failed to produce measurable antibody in vivo. The absence of an in vivo antibody response suggests that the young calf may be limited in its capacity to produce an adult-like antibody response to BCG.

Immaturity of the neonatal immune system contributes to an increased susceptibility of the young animal to infectious disease and may limit its capacity to develop a protective response to vaccination. Development of $\mathrm{T}$ helper lymphocyte function in infant mice is biased toward a Th2 response (Adkins, 2000), and CD4 ${ }^{+}$cells from neonatal mice appear to be intrinsically deficient in the functional maturation of Th1 lineage cells (Adkins et al., 2002). In support of such a Th2 bias in human infants are data indicating that human dendritic cells from cord blood, essential for priming of naïve $T$ cells and their subsequent differentiation into Th1 cells, have a profound defect in the expression of the Th1 cytokine, IL-12 (Goriely et al., 2001). Responses of human infants to viral vaccines are characterized by reduced IFN- $\gamma$ secretion and elevated serum antibody titers (Vekemans et al., 2002; Ota et al., 2004). Conse- 
quences of a Th2-biased response may include a reduced capacity of the neonate to respond effectively to vaccines that rely on a Th1 response for their efficacy. Vaccination of human newborns with BCG, in contrast, induces a potent Th1 response characterized by adult-like IFN$\gamma$ responses and reduced secretion of IL-4 and IL-5 by CD4 ${ }^{+}$lymphocytes (Marchant et al., 1999; Vekemans et al., 2001). Results from the present study indicate that the dairy calf, like the human infant, can generate an adult-like Th1 response when vaccinated during the first week of life with BCG. Because BCG is a potent inducer of Th1 responses (Flynn and Chan, 2001), it is not possible to make general conclusions regarding Th1 and Th2 balance in the newborn calf using the BCG sensitization/PPDb challenge model. Studies examining Th1 and Th2 balance in the young calf should consider sensitization protocols known to elicit balanced Th1/Th2 responses in adult cattle.

Cells comprising the PBMC populations from young and adult cattle were phenotyped using a panel of antibodies recognizing several leukocyte types (monocytes, $\mathrm{B}$ cells, and $\mathrm{T}$ cell subsets). The composition of cell populations from nonvaccinated and vaccinated calves was comparable throughout the experimental period suggesting that BCG vaccination did not influence the make-up of the population. Interestingly, the number of $\mathrm{CD} 4^{+}$and $\mathrm{CD} 8^{+} \mathrm{T}$ cells in the circulation of cattle is affected by infection by virulent $M$. bovis (Pollock et al., 1996). Differences in the composition of calf and adult cell populations were evident during the period of study. Age-related changes in the composition of calf PBMC populations were similar to previous observations indicating an increase in B cell percentage and a decrease in $\gamma \delta$ TCR+ cell percentage with increasing age (Senogles et al., 1978; Hein and Mackey, 1991; Pollock et al., 1996; Nonnecke et al., 1999). Changes in the proportion of lymphocyte subsets during the first weeks of life likely reflect maturation of the calf's immune system.

Effects of BCG vaccination on PBMC function in young and adult cattle were evaluated ex vivo using a battery of tests. Cells were stimulated with PWM and antigen. Because responses of adult cells to PWM typically are vigorous (Lutje and Black, 1992; Nonnecke et al., 1993; Franklin et al., 1994), the response to PWM served as a positive control for cell function in each assay. In all assays, mean responses to PWM during the experimental period were vigorous and exceeded mean responses of resting and antigen-stimulated cultures. Functional activities of calf and adult cells stimulated with PWM were comparable under most conditions. The exceptions were the greater proliferative responses by adult $\gamma \delta \mathrm{TCR}^{+}$cells relative to responses by calf $\gamma \delta \mathrm{TCR}^{+}$cells and the greater $\mathrm{TNF}-\alpha$ responses by vaccinated calves and adults relative to responses of nonvaccinated calves.

Effects of vaccination on the general responsiveness of PBMC populations to recall antigen were evaluated in a lymphocyte blastogenesis (DNA synthesis) assay and a flow cytometry-based cell proliferation assay. Demonstrable blastogenic responses to antigen (PPDb) were evident in vaccinated animals only. Recall responses of cells from vaccinated adults tended to be more vigorous than responses of cells from vaccinated calves suggesting that animal maturity influences antigen-specific responsiveness of vaccinated cattle. Antigen-induced proliferative responses of the PBMC population and T cell subsets were evaluated $7 \mathrm{wk}$ after primary vaccination when recall responses of adult cells in the blastogenesis assay were greater than those of calf cells. Antigen-induced proliferation of the PBMC population, and $\mathrm{CD}^{+}$and $\gamma \delta \mathrm{TCR}^{+} \mathrm{T}$ cell subsets was comparable in vaccinated young and adult cattle indicating that early vaccination promotes adult-like responses to PPD. The apparent discrepancy between blastogenesis and proliferation data cannot be explained; however, the proliferation assay was more informative regarding effects of vaccination on the responsiveness of PBMC populations to antigenic stimulation. The $\mathrm{CD}^{+}$and $\gamma \delta \mathrm{TCR}^{+} \mathrm{T}$ cell subsets from BCGvaccinated animals have been shown to respond to stimulation with mycobacterial antigens (Ladel et al., 1995; Hoft et al., 1998; Buddle et al., 2003b; Waters et al., 2003a, b, c). Hope et al. (2000), however, found no evidence of memory development in $\gamma \delta \mathrm{TCR}^{+}$cells in BCGvaccinated cattle that were 6 mo to $4 \mathrm{yr}$ of age. The $\mathrm{CD}^{+} \mathrm{T}$ cell subset from BCG-vaccinated mice, humans, and cattle responds to antigen (Hope et al., 2000; Flynn and Chan, 2001). In the present study, $\mathrm{CD} 8^{+}$cell populations from vaccinated calves and adult cattle were unresponsive to antigen. Reasons for the unresponsiveness of this T-cell subset are not known. Recent evidence indicating increased PPD-induced expression of CD25 (interleukin-2 receptor) on $\mathrm{CD}^{+} \mathrm{T}$ cells from BCG-vaccinated calves (Buddle et al., 2003b) substantiates the role of this subset in the response of the calf to BCG. Both $\mathrm{CD}^{+}$and $\mathrm{CD}^{+}$and possibly $\gamma \delta \mathrm{TCR}^{+} \mathrm{T}$ cells must be responsive to antigenic stimulation to assure protective immunity against mycobacterial infection (Flynn and Chan, 2001). In animals sensitized to or infected with mycobacteria, these cell subsets produce IFN- $\gamma$ and TNF- $\alpha$ in response to mycobacterial antigen (Tanaka et al., 1994; Lang et al., 1995; Hope et al., 2000; Flynn and Chan, 2001).

Protection against tuberculosis requires induction of a cell-mediated immune response characterized by the production of IFN- $\gamma$ (Flynn et al., 1993). Tumor necrosis factor- $\alpha$ is ineffective alone but synergizes with IFN- $\gamma$ 
to induce the production of reactive nitrogen intermediates by activated macrophages. These cytokines and nitrogen intermediates are essential players in freeradical antimycobacterial mechanisms of activated macrophage (Flynn and Chan, 2001). Tumor necrosis factor- $\alpha$ is necessary for granuloma formation, a process essential for containment of the organism. Mice deficient in TNF- $\alpha$ and TNF- $\alpha$ receptor fail to develop organized granulomas and succumb to mycobacterial infections (Flynn et al., 1995; Ehlers et al., 1999). In the present study, PPD-specific IFN- $\gamma$ and TNF- $\alpha$ responses of circulating leukocytes from calves were comparable and in some instances greater than parallel responses of adult cells. Analysis of NO production using the Greiss reaction indicated that responses of vaccinated calves and adults were similar with regard to antigen-specific production of NO. These data suggest that the calf can generate a Th1-like response with potential antimycobacterial capacity.

Although constraints associated with the design of the present study prevented challenge with virulent $M$. bovis, Buddle et al. (2003b) did challenge BCG-vaccinated calves with virulent $M$. bovis. Vaccination at $8 \mathrm{~h}$ or at 6 wk of age was shown to protect against challenge, whereas vaccination at birth and revaccination at wk 6 reduced protection. The authors suggest that the higher PPD-specific IFN- $\gamma$ and IL-2 responses of revaccinated calves might result in an immunopathological response contributing to the development of tuberculous lesions. Calves in the present study were also revaccinated 6 wk after primary vaccination. Antigen-induced NO responses of vaccinated calves and adults decreased substantially by $7 \mathrm{~d}$ after revaccination, indicating that revaccination may have inhibited an important effector of the antimycobacterial response. By wk 2 after revaccination, responses were comparable to those immediately before revaccination suggesting that the effects of revaccination were transient. Cytokine production was not evaluated at wk 1 after revaccination; however, measurements were taken at wk 2 and 5 after revaccination. Antigen-induced secretion of IFN- $\gamma$ appeared not to be affected negatively by revaccination; however, TNF- $\alpha$ responses of vaccinated calves and adults tended to lower after revaccination. These results suggest that revaccination may influence $\mathrm{PPD}$-specific NO and TNF$\alpha$ responses critical in the development of protective immunity. Responses of vaccinated calves and adult cattle to the cervical skin-fold tests performed $5 \mathrm{wk}$ after revaccination were comparably robust, suggesting that the effects of revaccination on in vivo, cell-mediated immune response of the calf and adult were similar. As noted by Buddle et al. (2003b), additional studies are needed to determine whether the interval between vaccination and revaccination influences or compromises the degree of protection afforded the neonate.

Although vaccinated calves developed adult-like cellmediated immune responses in vivo and ex vivo, their humoral responses (characterized by antibody in serum and in supernatants from antigen-stimulated PBMC cultures) were nonexistent relative to responses of vaccinated adult cattle. Differences between neonatal and adult antibody responses are intriguing even though antibody is not considered important in the control of tuberculosis (Flynn and Chan, 2001). Elevated antibody levels in sera from calves but not adults at the time of primary vaccination were likely attributable to maternal antibody from ingested colostrum. The relatively short half-life (11.5 to $16 \mathrm{~d}$ ) of colostrum-derived antibody (Sasaki et al., 1976) likely contributed to the subsequent decline in antibody levels in the calves. Reasons for the inability of vaccinated calves to mount an antibody response to BCG vaccination were not determined, however, maternal antibody may have been a contributory factor. Maternal antibodies acquired transplacentally or through the ingestion of colostrum are important for protection of neonates; however, numerous reports indicate that they also inhibit responses to infection and immunization (Barrington and Parish, 2001; Endsley et al., 2003; Glezen, 2003; Siegrist, 2003). Other factors may have influenced antibody responses of vaccinated calves. Blood mononuclear leukocytes harvested from vaccinated calves 6 wk after primary vaccination produced substantially fewer antibodies in PPDb-stimulated cultures than did antigen-stimulated cells from vaccinated adults. At this time, antibody was not detected in the circulation of vaccinated calves. These data suggest that $\mathrm{CD} 4^{+} \mathrm{T}$ cell or $\mathrm{B}$ cell functions essential for production of antimycobacterial antibody were reduced in the vaccinated calf relative to the vaccinated adult, although responses of vaccinated calves were greater than those of nonvaccinated calves. Buddle et al. (2003b) recently demonstrated that BCG vaccination in young calves increases expression of IFN- $\gamma$ and IL-4 mRNA by PPDb-stimulated PBMC, although IFN- $\gamma$ mRNA was 19 -fold higher than IL-4 mRNA. Evidence of a comparatively weak IL-4 response in BCGvaccinated calves may explain the weak but detectable antibody response by PPD-stimulated cells from vaccinated calves observed in the present study.

The BCG sensitization and PPDb (or alternatively virulent $M$. bovis) challenge model has several applications in studies of the immune system of the calf and the neonate in general. Pivotal applications include the continued evaluation of early vaccination (i.e., single or multiple vaccinations) on long-term tuberculosis resistance in cattle, the development of improved vaccines against other intracellular pathogens, and development 
of an animal model for optimizing BCG vaccination in human infants (Buddle et al., 2003a, b; Hewinson et al., 2003). From the perspective of the animal scientist considering the effects of nutritional status, individual micronutrients, or endocrines on the calf's immune system, this model has several appealing characteristics. Firstly, because BCG is attenuated, vaccination is not associated with horizontal transmission of the organism. Secondly, PPD-elicited recall responses in cattle have been described in detail allowing effects of potential modulators (nutritionally based or otherwise) on the bovine immune system to be analyzed in detail. As an example, this model is currently being used to evaluate the effects of dietary protein and energy on the composition and functional capacity of the immune system of the milk replacer-fed dairy calf (Foote et al., 2003).

\section{CONCLUSIONS}

Vaccination of young and adult dairy cattle with $M$. bovis BCG resulted in the development of antigen-specific memory that was detectable ex vivo and in vivo. Early vaccination of calves was associated with a Th1like response to antigen comparable to the response of adult cattle sensitized in an identical manner. Responses were characterized by antigen-induced proliferation of $\mathrm{CD}^{+}$and $\gamma \delta \mathrm{TCR}^{+} \mathrm{T}$ cell subsets, secretion of IFN- $\gamma$, TNF- $\alpha$, and NO, and cutaneous delayed-type hypersensitivity. Vaccinated adults produced measurable amounts of antibody in vivo and ex vivo, whereas responses of vaccinated calves were weak or nonexistent, suggesting that animal maturity influences antigen-elicited antibody responses. Overall, these results demonstrate that the bovine neonate can respond competently to a potent inducer of cell-mediated immunity. The BCG sensitization/PPD challenge model might be useful in evaluating effects of various modulators of immune function, including specific micronutrients or endocrines, on the ontogeny of the adaptive arm of the bovine immune system.

\section{ACKNOWLEDGMENTS}

The authors thank Ryan Cook, Nancy Eischen, Donald McDorman, and Theresa Waters in the Periparturient Diseases of Cattle Research Unit and Bacterial Diseases of Livestock Research Unit, National Animal Disease Center, for technical support, and D. Hammell at the Research Farm, Land O'Lakes, Inc. for implementation of calf-related procedures. Authors also thank Bryce Buddle, Wallace Animal Research Center, New Zealand, for critical review of the manuscript.

\section{REFERENCES}

Adkins, B. 2000. Development of neonatal Th1/Th2 function. Int. Rev. Immunol. 19:157-171.

Adkins, B., Y. Bu, and P. Guevara. 2002. Murine neonatal CD4+ lymph node cells are highly deficient in the development of antigen-specific Th1 function in adoptive adult hosts. J. Immunol. 169:4998-5004.

Barrington, G. M., and S. M. Parish. 2001. Bovine neonatal immunology. Vet. Clin. North Am. Food Anim. Pract. 17:463-476.

Bolin, C. A., D. L. Whipple, K. V. Khanna, J. M. Risdahl, P. K. Peterson, and T. W. Molitor. 1997. Infection of swine with Mycobacterium bovis as a model of human tuberculosis. J. Infect. Dis. 176:1559-1566.

Buddle, B. M., J. M. Pollock, M. A. Skinner, and D. N. Wedlock. 2003a. Development of vaccines to control bovine tuberculosis in cattle and relationship to vaccine development for other intracellular pathogens. Int. J. Parasitol. 33:555-566.

Buddle, B. M., D. N. Wedlock, N. A. Parlane, A. L. Corner, G. W. Lisle, and M. A. Skinner. 2003b. Revaccination of neonatal calves with Mycobacterium bovis BCG reduces the level of protection against bovine tuberculosis induced by a single vaccination. Infect. Immun. 71:6411-6419.

Clement, L. T., P. E. Vink, and G. E. Bradley. 1990. Novel immunoregulatory functions of phenotypically distinct subpopulations of CD4+ cells in the human neonate. J. Immunol. 145:102-108.

Ehlers, S. J., J. Benini, S. Kutsch, R. Endres, E. T. Rietschel, and K. Pfeffer. 1999. Fatal granuloma necrosis without exacerbated mycobacterial growth in tumor necrosis factor receptor p55 genedeficient mice intravenously infected with Mycobacterium avium. Infect. Immun. 67:3571-3579.

Endsley, J. J., J. A. Roth, J. Ridpath, and J. Neill. 2003. Maternal antibody blocks humoral but not T cell responses to BVDV. Biologicals 31:123-125.

Flynn, J. L., and J. Chan. 2001. Immunology of tuberculosis. Annu. Rev. Immunol. 19:93-129.

Flynn, J. L., J. Chan, K. J. Triebold, D. K. Dalton, T. A. Stewart, and B. R. Bloom. 1993. An essential role for interferon gamma in resistance to Mycobacterium tuberculosis. J. Exp. Med. 178:2249-2254.

Flynn, J. L., M. M. Goldstein, J. Chan, K. J. Triebold, K. Pfeffer, C. J. Lowenstein, R. Schreiber, T. W. Mak, and B. R. Bloom. 1995. Tumor necrosis factor-alpha is required in the protective immune response against Mycobacterium tuberculosis in mice. Immunity 2:561-572.

Foote, M. R., B. J. Nonnecke, W. R. Waters, M. R. Fowler, B. Miller, T. E. Johnson, H. B. Perry, and D. C. Beitz. 2003. Effects of the plane of nutrition on the proliferation of blood lymphocyte subsets from neonatal calves vaccinated with Mycobacterium bovis, bacillus Calmette-Guérin (BCG). 2003 Experimental Biology meeting abstracts. Online. Available: http://select.biosis.org/faseb. FASEB J. 17: Abstract \# 698.1.

Franklin, S. T., J. W. Young, and B. J. Nonnecke. 1994. Proliferation and phenotype of bovine mononuclear leukocytes in cultures stimulated by pokeweed mitogen. J. Dairy Sci. 77:3592-3600.

Glezen, W. P. 2003. Effect of maternal antibodies on the infant immune response. Vaccine 21:3389-3392.

Goriely, S., B. Vincart, P. Stordeur, J. Vekemans, F. Willems, M. Goldman, and D. De Wit. 2001. Deficient IL-12 (p35) gene expression by dendritic cells derived from neonatal lymphocytes. J. Immunol. 166:2141-2146.

Hein, W. R., and C. R. Mackey. 1991. Prominence of $\gamma \delta$ T cells in the ruminant immune system. Immunol. Today 12:30-33.

Hewinson, R. G., H. M. Vordermeier, and B. M. Buddle. 2003. Use of the bovine model of tuberculosis for the development of improved vaccines and diagnostics. Tuberculosis (Edinb.) 83:119-130.

Hoft, D. F., R. M. Brown, and S. T. Roodman. 1998. Bacille Calmette Guerin vaccination enhances human $\gamma \delta$ T cell responsiveness to mycobacteria suggestive of a memory like phenotype. J. Immunol. 161:1045-1054.

Hope, J. C., L. S. Kwong, P. Sopp, R. A. Collins, and C. J. Howard. 2000. Dendritic cells induce CD4+ and CD8+ T-cell responses to 
Mycobacterium bovis and M. avium antigens in bacille Calmette Guerin vaccinated and nonvaccinated cattle. Scand. J. Immunol. $52: 285-291$.

Hope, J. C., P. Soop, and C. J. Howard. 2002. NK-like CD8(+) cells in immunologically naíve neonatal calves that respond to dendritic cells infected with Mycobacterium bovis BCG. J. Leukoc. Biol. 71:184-194.

Ladel, C. H., J. Hess, S. Daugelat, P. Mombaerts, S. Tonegawa, and S. H. Kaufmann. 1995. Contribution of $\mathrm{a} / \mathrm{b}$ and $\mathrm{g} / \mathrm{d} \mathrm{T}$ lymphocytes to immunity against $M y$ cobacterium bovis bacillus Calmette Guerin: Studies with T cell receptor deficient mice. Eur. J. Immunol. 25:838-846.

Lang, F., M. A. Peyrat, P. Constant, F. Davodeau, J. David-Ameline, Y. Poquet, H. Vie, J. J. Fournie, and M. Bonneville. 1995. Early activation of human $\mathrm{V} \gamma 9 \sigma 2 \mathrm{~T}$ cell broad cytotoxicity and TNF production by non-peptidic mycobacterial ligands. J. Immunol. 154:5986-5994

Lutje, V., and S. J. Black. 1992. Analysis of pokeweed mitogen-induced in vitro proliferative and antibody responses of bovine lymphocytes. Res. Vet. Sci. 52:236-242.

Marchant, A., T. Goetghebuer, M. O. Ota, I. Wolfe, S. J. Ceesay, D. DeGroote, T. Corrah, S. Bennett, J. Wheeler, K. Huygen, and P. Aaby. 1999. Newborns develop Th1-type immune responses to Mycobacterium bovis bacillus Calmette-Guérin vaccination. J. Immunol. 163:2249-2255.

Morein, B., I. Abusugra, and G. Blomquist. 2002. Immunity in neonates. Vet. Immunol. Immunopathol. 87:207-213.

Nickerson, S. C., and B. J. Nonnecke. 1986. Tuberculin elicited cellular immune response in the lactating mammary gland vaccinated intramammarily with Mycobacterium bovis. Vet. Immunol. Immunopathol. 13:39-50.

Nonnecke, B. J., L. A. Elsken, and M. E. Kehrli, Jr. 1986. Local and systemic immune response in the cow after intramammary vaccination during lactation. Vet. Immunol. Immunopathol. 11:31-44.

Nonnecke, B. J., S. T. Franklin, and S. L. Nissen. 1991. Leucine and its catabolites alter mitogen-stimulated DNA-synthesis by bovine lymphocytes. J. Nutr. 121:1665-1672.

Nonnecke, B. J., S. T. Franklin, T. A. Reinhardt, and R. L. Horst. 1993. In vitro modulation of proliferation and phenotype of resting and mitogen-stimulated bovine mononuclear leukocytes by 1,25dihydroxyvitamin D3. Vet. Immunol. Immunopathol. 38:75-89.

Nonnecke, B. J., R. L. Horst, W. R. Waters, P. Dubeski, and J. A. Harp. 1999. Modulation of fat-soluble vitamin concentrations and blood mononuclear leukocytes populations in milk replacer-fed calves by dietary vitamin A and beta-carotene. J. Dairy Sci. 82:2632-2641.

Ota, M. O., J. Vekemans, S. E. Schlegel-Haueter, K. Fielding, M. Sanneh, M. Kidd, M. J. Newport, P. Aaby, H. Whittle, P. H. Lambert, K. P. McAdam, C. A. Siegrist, and A. Marchant. 2002. Influence of Mycobacterium bovis bacillus Calmette-Guérin on antibody and cytokine responses to human neonatal vaccination. J. Immunol. 168:919-925.
Ota, M. O., J. Vekemans, S. E. Schlegel-Haueter, K. Fielding, H. Whittle, P. H. Lambert, K. P. McAdam, C. A. Siegrist, and A. Marchant. 2004. Hepatitis B immunisation induces higher antibody and memory Th2 responses in newborns than in adults. Vaccine 22:511-519.

Pollock, J. M., D. A. Pollock, D. G. Campbell, R. M. Girvin, A. D. Crockard, S. D. Neill, and D. P. Mackie. 1996. Dynamic changes in circulating and antigen-responsive T cell subpopulations postMycobacterium bovis infection in cattle. Immunology 87:236-241.

Rajaraman, V., B. J. Nonnecke, S. T. Franklin, D. C. Hammell, and R. L. Horst. 1998. Effect of vitamins A and E on nitric oxide production by blood mononuclear leukocytes from neonatal calves fed milk replacer. J. Dairy Sci. 81:3278-3285.

Ridge, J. P., E. J. Fuchs, and P. Matzinger. 1996. Neonatal tolerance revisited: Turning on newborn T cells with dendritic cells. Science 271:1723-1726.

Sasaki, M., C. L. Davis, and B. L. Larson. 1976. Production and turnover of IgG1 and IgG2 immunoglobulins in the bovine around parturition. J. Dairy Sci. 59:2046-2055.

Senogles, D. R., C. C. Muscoplat, P. S. Paul, and D. W. Johnson. 1978. Ontogeny of circulating B lymphocytes in neonatal calves. Res. Vet. Sci. 25:34-36.

Siegrist, C. A. 2000. Vaccination in the neonatal period and early infancy. Int. Rev. Immunol. 19:195-219.

Siegrist, C. A. 2003. Mechanisms by which maternal antibodies influence infant vaccine responses: Review of hypotheses and definition of main determinants. Vaccine 21:3406-3412.

Tanaka, Y., S. Sano, E. Nieves, G. De Libero, D. Rosa, R. L. Modlin, M. B. Brenner, B. R. Bloom, and C. T. Morita. 1994. Non-peptide ligands for human $\gamma \delta \mathrm{T}$ cells. Proc. Natl. Acad. Sci. USA 91:8175-8179.

Vekemans, J., A. Amedei, M. O. Ota, M. M. D’Elios, T. Goetghebuer, J. Ismali, M. J. Newport, G. Del Prete, M. Goldman, K. P. W. J. McAdam, and A. Marchant. 2001. Neonatal bacillus CalmetteGuérin vaccination induces adult-like IFN- $\gamma$ production by $\mathrm{CD} 4+$ T lymphocytes. Eur. J. Immunol. 31:1531-1535.

Vekemans, J., M. O. Ota, E. C. Wang, M. Kidd, L. K. Borysiewicz, H. Whittle, K. P. McAdam, G. Morgan, and A. Marchant. 2002. $\mathrm{T}$ cell responses to vaccines in infants: defective IFN gamma production after oral polio vaccination. Clin. Exp. Immunol. 127:495-498.

Waters, W. R., B. J. Nonnecke, M. R. Foote, A. C. Maue, T. E. Rahner, M. V. Palmer, D. L. Whipple, R. L. Horst, and D. M. Estes. 2003a. Mycobacterium bovis bacille Calmette-Guérin vaccination of cattle: Activation of bovine CD4+ and gamma delta TCR+ cells and modulation by 1,25-dihydroxyvitamin D3. Tuberculosis (Edinb.) 83:287-297.

Waters, W. R., M. V. Palmer, S. C. Olsen, R. E. Sacco, and D. L. Whipple. 2003b. Immune responses of elk to Mycobacterium bovis bacillus Calmette Guerin vaccination. Vaccine 21:1518-1526.

Waters, W. R., T. E. Rahner, M. V. Palmer, D. Cheng, and B. J. Nonnecke. 2003c. Expression of L-selectin (CD62L), CD44, and CD25 on activated bovine T cells. Infect. Immun. 71:317-326. 